\title{
(6) OPEN ACCESS \\ UK key performance indicators and quality assurance standards for colonoscopy
}

\author{
Colin J Rees, ${ }^{1,2,3}$ Siwan Thomas Gibson, ${ }^{4}$ Matt D Rutter, ${ }^{2,3,5}$ Phil Baragwanath, ${ }^{6}$ \\ Rupert Pullan, ${ }^{7}$ Mark Feeney, ${ }^{7}$ Neil Haslam, ${ }^{8}$ on behalf of: the British Society \\ of Gastroenterology, the Joint Advisory Group on GI Endoscopy, the Association of \\ Coloproctology of Great Britain and Ireland
}

\begin{abstract}
${ }^{1}$ Department of Gastroenterology, South Tyneside NHS Foundation Trust, South Shields, UK ${ }^{2}$ Durham University School of Medicine, Pharmacy and Health

${ }^{3}$ Northern Region Endoscopy Group

${ }^{4}$ Imperial College Endoscopy Unit, St Mark's Hospital, London, UK

${ }^{5}$ Department of

Gastroenterology, University Hospital of North Tees,

Stockton-on-Tees, UK

${ }^{6}$ University Hospital of Coventry \& Warwickshire NHS Trust, Coventry, UK

7 South Devon Healthcare NHS Foundation Trust, Torquay, UK ${ }^{8}$ Royal Liverpool University Hospital
\end{abstract}

Correspondence to Professor Colin J Rees, Department of Gastroenterology, South Tyneside District Hospital, South Shields, NE34 OPL, UK; colin.rees@stft.nhs.uk

Received 11 April 2016 Revised 8 July 2016 Accepted 17 July 2016 Published Online First 16 August 2016

\section{CrossMark}

To cite: Rees CJ, Thomas Gibson S, Rutter MD, et al. Gut 2016;65:1923-1929.

\section{ABSTRACT}

Colonoscopy should be delivered by endoscopists performing high quality procedures. The British Society of Gastroenterology, the UK Joint Advisory Group on GI Endoscopy, and the Association of Coloproctology of Great Britain and Ireland have developed quality assurance measures and key performance indicators for the delivery of colonoscopy within the UK. This document sets minimal standards for delivery of procedures along with aspirational targets that all endoscopists should aim for.

\section{INTRODUCTION}

Colonoscopy is the 'gold standard' investigation for assessment of the large bowel, allowing diagnosis, biopsying, and therapy to be undertaken. Colonoscopy detects and prevents colorectal cancer, ${ }^{1}$ and is important in the diagnosis and treatment of nonneoplastic conditions. Colonoscopy can lead to rare but serious complications ${ }^{2-5}$ and poor quality colonoscopy is associated with increased rates of interval cancers. ${ }^{6}$ The quality of UK colonoscopy has improved over recent years, ${ }^{7} 8$ but unacceptable variation in practice still exists. ${ }^{8} 9$ Additionally the demand for colonoscopy is increasing. ${ }^{10-13}$

In 2013, the Joint Advisory Group on GI Endoscopy (JAG), the British Society of Gastroenterology (BSG), and the Association of Coloproctology of Great Britain and Ireland (ACPGBI) commissioned a working group to review existing and define new quality assurance (QA) measures and key performance indicators (KPI) for colonoscopy. The three governing bodies nominated members of the working group who authored the paper. Working group members took responsibility for groups of standards and undertook a review of existing literature, existing standards, and evidence for those standards. Where evidence was available it was used to frame the standards. Where no clear evidence existed then existing standards and the expert opinion of the working group were used to arrive at agreed standards. The standards were reviewed and amended by the governing groups of the JAG, BSG and ACPGBI and then further edited by the authors. The document concentrates on the agreed standards and considers why a particular standard was agreed.

This document establishes clear minimal standards for KPI and QA measures. Where practice falls below these levels then interventions are required to raise the performance of those colonoscopists. Where the authors believed that higher standards would be ideal an aspirational target was set. The authors believe that this is the level that all colonoscopists should be aiming for to provide high quality practice.

\section{CAECAL INTUBATION RATE}

Minimal unadjusted caecal intubation 90\%. Colonoscopists should aspire to achieve 95\% unadjusted caecal intubation.

Photographic documentation of caecal intubation should be obtained with images taken of clear caecal landmarks or of terminal ileum.

It is important to examine the whole colon, but practice is variable. ${ }^{7} 1415$ The consequences of an incomplete examination are missed diagnosis and failure to prevent interval cancers. ${ }^{16}{ }^{17}$ In a British Society of Gastroenterology (BSG) audit of all colonoscopies performed within the UK over a 2 week period, ${ }^{8}$ the unadjusted caecal intubation rate (CIR) was $92.3 \%$ rising to $95.8 \%$ following adjustment for impassable strictures and poor bowel preparation. A further UK study ${ }^{9}$ demonstrated an unadjusted CIR at 92.5\% (95\% CI 91.2\% to 92.6\%). The English Bowel Cancer Screening Programme (BCSP) published the results of the first 3 years of screening ${ }^{18}$ with an unadjusted CIR of 95.2\% (range 76.2$100 \%)$. Given the CIR is in excess of $90 \%$ for large series, this unadjusted rate should be the minimal standard. The BCSP demonstrates that a higher CIR can be achieved in a large programme and a standard of $95 \%$ unadjusted CIR should be aspired to.

\section{ADENOMA DETECTION RATE}

Minimal adenoma detection rate should be $15 \%$. Aspirational adenoma detection rate should be $20 \%$.

Where polyp detection rate can be shown to be accurate it may be used as a marker of ADR.

Thorough examination of the colonic mucosa is crucial to maximise the effectiveness of colonoscopy as a diagnostic test. The adenoma detection rate (ADR) is the proportion of colonoscopies where one or more adenomas are detected. The $\mathrm{ADR}$ is the marker most commonly used for this purpose. Lower ADRs are associated with higher rates of interval cancers. ${ }^{6}{ }^{19}$ Colonoscopists with an ADR $<20 \%$ had a hazard ratio for interval cancer that was 10 times higher than colonoscopists with an ADR $>20 \%$. A recent UK study 


\begin{tabular}{|c|c|c|c|}
\hline Quality indicator & Minimal standard & Aspirational target & Comment \\
\hline Caecal intubation rate (CIR) (unadjusted) & $90 \%$ & $95 \%$ & $\begin{array}{l}\text { Photographic proof of ileocaecal valve, terminal ileum, anastomosis or } \\
\text { appendix orifice required in all cases }\end{array}$ \\
\hline $\begin{array}{l}\text { Adenoma detection rate (ADR) in general all } \\
\text { patient population (not screening) }\end{array}$ & $15 \%$ & $20 \%$ & $\begin{array}{l}\text { ADR is the quality standard. Given the difficulty in reporting ADR then } \\
\text { polyp detection rate or polypectomy rate may be used where it has } \\
\text { been demonstrated to reflect accurately ADR for that unit/clinician }\end{array}$ \\
\hline $\begin{array}{l}\text { Bowel preparation of sufficient diagnostic } \\
\text { quality to not warrant repeat or alternative } \\
\text { test }\end{array}$ & $90 \%$ & $95 \%$ & \\
\hline Rectal retroversion rate & $90 \%$ & & \\
\hline $\begin{array}{l}\text { Colonoscopy withdrawal time (for negative } \\
\text { procedures) }\end{array}$ & Mean of $\geq 6 \min$ & Mean of $\geq 10 \min$ & \\
\hline $\begin{array}{l}\text { Sedation level for age }<70 \\
\text { Median total dose: } \\
\leq 50 \mathrm{mg} \text { pethidine ( } \leq 100 \mu \mathrm{g} \text { fentanyl) } \\
\leq 5 \mathrm{mg} \text { midazolam (or equivalent drugs) }\end{array}$ & Auditable outcome & & \\
\hline $\begin{array}{l}\text { Sedation level } \\
\text { for age } \geq 70 \\
\text { Median total dose: } \\
\leq 25 \mathrm{mg} \text { pethidine ( } \leq 50 \mu \mathrm{g} \text { fentanyl) } \\
\leq 2 \mathrm{mg} \text { midazolam (or equivalent drugs) }\end{array}$ & Auditable outcome & & \\
\hline $\begin{array}{l}\text { Number of colonoscopies undertaken by } \\
\text { endoscopist (or directly supervising trainee in } \\
\text { room) per year }\end{array}$ & 100 & & $\begin{array}{l}\text { If numbers }<150 \text { then other key performance indicators, eg, CIR and } \\
A D R \text {, should be scrutinised more closely and, if concerns, action taken }\end{array}$ \\
\hline Polyp retrieval rate & $\geq 90 \%$ & & \\
\hline $\begin{array}{l}\text { Tattooing of all lesions } \geq 20 \mathrm{~mm} \text { and/or } \\
\text { suspicious of cancer outside of rectum and } \\
\text { caecum }\end{array}$ & $\begin{array}{l}\text { Tattoo placed in } \\
100 \% \text { of cases }\end{array}$ & & Tattoo according to trust policy \\
\hline Diagnostic biopsies for unexplained diarrhoea & $\begin{array}{l}\text { Rectal biopsies } \\
\text { taken in } 100 \% \text { of } \\
\text { cases }\end{array}$ & $\begin{array}{l}\text { Right and left colonic } \\
\text { biopsies taken in } 100 \% \text { of } \\
\text { cases }\end{array}$ & $\begin{array}{l}\text { Aspiration should be that a minimum of two right and two left colon } \\
\text { biopsies should be taken, but as minimum standard rectal biopsies } \\
\text { should always be taken (unless there is a contraindication) }\end{array}$ \\
\hline Post-colonoscopy colorectal cancer & Auditable outcome & & $\begin{array}{l}\text { All post-colonoscopy colorectal cancers diagnosed within } 3 \text { years of a } \\
\text { colonoscopy should be reported as adverse events and each unit } \\
\text { should have a policy for capturing post-colonoscopy colorectal cancer } \\
\text { data }\end{array}$ \\
\hline Comfort level & Auditable outcome & & $\begin{array}{l}\text { Units should audit this and }<10 \% \text { of patients should have moderate or } \\
\text { severe discomfort }\end{array}$ \\
\hline Overall colonoscopic perforation rate & $<1$ in 1000 & $<1$ in 3000 & \\
\hline Diagnostic colonoscopic perforation rate & $<1$ in 2000 & $<1$ in 4000 & \\
\hline $\begin{array}{l}\text { Colonoscopic perforation rate where } \\
\text { polypectomy performed }\end{array}$ & $<1$ in 500 & $<1$ in 1500 & \\
\hline $\begin{array}{l}\text { Colonoscopic perforation rate where dilatation } \\
\text { performed }\end{array}$ & $<3 \%(<1$ in 33$)$ & $<1 \%(<1$ in 100$)$ & \\
\hline $\begin{array}{l}\text { Diagnostic flexible sigmoidoscopy (FS) } \\
\text { perforation rate }\end{array}$ & $<1$ in 5000 & $<1$ in 10000 & \\
\hline Colorectal stenting perforation rate & $<10 \%$ & $<5 \%$ & \\
\hline $\begin{array}{l}\text { Post-polypectomy bleeding rate (intermediate } \\
\text { severity or higher) }\end{array}$ & $<1$ in 200 & $<1$ in 1000 & \\
\hline Unplanned admission rate & $\begin{array}{l}\text { Auditable outcome; } \\
\text { review every case }\end{array}$ & & \\
\hline Use of reversal agents & $\begin{array}{l}\text { Auditable outcome; } \\
\text { review every case }\end{array}$ & & \\
\hline
\end{tabular}

Auditable outcome-endoscopy units should audit these measures.

Additional recommendations

Management of polyps - all units should have a policy for management of polyps including a policy for dealing with large and large sessile polyps.

Tattoo policy-all units should have a policy for tattooing of polyps and cancers and should audit whether this is being followed.

Rectal examination should be performed at colonoscopy or before endoscopy. All units should audit practice.

Terminal ileal intubation—all units should audit practice and agree local policy.

demonstrated wide variation in ADR with a global ADR (excluding screening colonoscopy) of $15.9 \% .^{9}$

ADR will vary according to the nature of the population colonoscoped and the indication for the procedure. However, even allowing for variation in population ADR, the current $10 \% \mathrm{UK}$ minimum is too low. The $20 \%$ ADR reported by Kaminski et $a l^{6}$ is aspirational, but was for a screening age population. Therefore for the UK all age population a standard of $15 \%$ has been set with an aspirational target of $20 \%$.
Measuring ADR currently requires interrogation of pathology databases to obtain polyp histology. The polyp detection rate (PDR) is often much more simple to obtain. ADR is the key performance measure but where it can be demonstrated that a ratio between an endoscopist's PDR and ADR has been developed and validated, then PDR may be an acceptable surrogate marker ${ }^{20-22}$ with the minimum value set to ensure an ADR of $15 \%(20 \%$ aspiration) is achieved. It is recommended that review of the validity of PDR to represent ADR is audited on an ongoing basis. 


\section{BOWEL PREPARATION}

Bowel preparation of at least adequate quality to be achieved in $90 \%$ of patients.

Aspirational: bowel preparation of at least adequate quality to be achieved in $95 \%$ of patients.

Aspirational: easy to use, validated national bowel preparation scale should be developed.

High quality colonoscopy cannot occur without good quality bowel preparation, which maximises CIRs and the detection of neoplasia. This is highlighted by the 2013 ESGE position statement $^{23}$ issued to guide European countries setting up bowel cancer screening services. Evidence in the UK shows that $22 \%$ of failed colonoscopies were due to poor bowel preparation. ${ }^{8}$

There is a lack of evidence for one superior bowel cleansing agent, ${ }^{23}$ therefore units should select their preferred agent based on local experience and BSG guidance. ${ }^{24}$

At least five validated bowel preparation evaluation scales exist $^{25-29}$ however, all involve relatively complex scoring systems and are not in common usage in the UK. The BCSP uses a four point scale: excellent, adequate, complete despite poor preparation, or failed due to poor preparation. ${ }^{30}$ Despite the subjectivity of this scale we recommend this or a similar scale is recorded for all colonoscopies.

The minimum proposed CIR is 90\%, and audit suggesting that excellent or adequate bowel preparation can be achieved by the BCSP in $94.2 \%$ of patients ${ }^{18}$ means that we recommend bowel preparation be excellent or adequate in at least $90 \%$ of patients, and in line with an aspirational CIR of 95\%, would have an aspirational standard of $95 \%$.

We also have an aspiration to see validation of the BCSP scale or a similar easy-to-use tool to become the UK standard bowel preparation scale.

\section{RECTAL EXAMINATION AND RECTAL RETROFLEXION}

Rectal examination or omission should be recorded in 100\% of cases.

Rectal retroflexion should be performed in $90 \%$ of cases. Digital rectal examination

Digital rectal examination (DRE) has been recommended as a standard part of endoscopic examination of the lower gastrointestinal tract with the aim of preparing the anal canal for the insertion of the scope and to examine the anal canal and lower rectum for pathology. ${ }^{31}$ A comparison of DRE and rectal retroflexion showed that DRE was sensitive for detection of abnormalities in the lower rectum and upper anal canal that were subsequently demonstrated on retroflexion of the endoscope. ${ }^{32}$

\section{Rectal retroflexion}

A number of studies have demonstrated increased detection of pathology by using retroflexion after standard views of the rectum have been obtained. An increase in yield of $8 \%$ was demonstrated in one study, ${ }^{33}$ with others demonstrating a yield of around 2-2.5\%. ${ }^{34-37}$ Manoeuvre success rates between $94 \%{ }^{36}$ and $100 \%{ }^{38}$ have been reported. Retroversion may rarely cause rectal injury ${ }^{39} 40$ with the estimated the risk $0.01 \%$. $^{41}$ We recommend that digital rectal examination and retroflexion are attempted in all cases.

\section{COLONOSCOPY WITHDRAWAL TIME}

Minimum mean withdrawal time of $6 \mathrm{~min}$ for negative procedures.
Aspirational: mean withdrawal time of $10 \mathrm{~min}$ for negative procedures.

Withdrawal times should be routinely recorded and audited.

Colonoscopy withdrawal times (CWTs) of $>6$ min for negative procedures have frequently been linked to higher ADR, ${ }^{42}$ with the suggestion that longer times are beneficial, ${ }^{43} 44$ and an increased ADR for trainees when the CWT was over 10 min. $^{45}$ An increased withdrawal time may also be associated with improved technique such as position change, better aspiration of fluid pools, and more attention to deep folds and difficult corners. ${ }^{46}$ Other studies, however, have not shown a link between CWT and polyp detection using the cut-off of $6 \mathrm{~min}^{47}$ or 7 min. $^{48}$

Mean withdrawal times for negative procedures should be more than 6 min with an aspirational goal of achieving $10 \mathrm{~min}$. This KPI should be linked to the ADR or PDR such that a low CWT with a low ADR strongly suggests inadequate technique (in the absence of other explanations such as population group) that requires managed changes in performance.

\section{SEDATION}

Sedation level for age <70: median total dose $\leq 50 \mathrm{mg}$ pethidine ( $\leq 100 \mu \mathrm{g}$ fentanyl), $\leq 5 \mathrm{mg}$ midazolam or equivalent drugs. Sedation level for age $\geq 70$ : median total dose $\leq 25 \mathrm{mg}$ pethidine ( $\leq 50 \mu \mathrm{g}$ fentanyl), $\leq 2 \mathrm{mg}$ midazolam or equivalent drugs.

In the UK, the majority of colonoscopies are performed under conscious sedation. These standards are based upon the current BSG sedation guidelines. ${ }^{49}$ The recent BSG audit reported $>90 \%$ of sedation practice was in line with these guidelines. More than $10 \%$ of procedures were performed without sedation, with nitrous oxide used as the sole sedative agent in $4.2 \%$ of procedures. Reversal agents were required in only $0.1 \%$ of procedures. Similar sedation practice was reported in a large regional study, ${ }^{50}$ with $85.6 \%$ of procedures performed under conscious sedation. These data suggest that conscious sedation can be performed safely and it appears to be satisfactory in the majority of cases, accepting the limitations of current methods of measuring comfort. Current sedation standards should be maintained.

\section{NUMBER OF COLONOSCOPIES PERFORMED PER ANNUM}

Minimum number colonoscopies to achieve competence: 200. Minimum numbers per annum to maintain competence: 100.

\section{Achieving competency}

Accepting that CIR is usually self-reported, the literature reports a number of studies that evaluate how many procedures are required to consistently reach a CIR of $90 \%$. Current UK standards require at least 200 procedures to achieve competency, strengthened with a publication ${ }^{51}$ showing competency (based on a CIR of $90 \%$ ) is reached by $41 \%$ of trainees after 200 procedures. Similar figures of between 175 and 400 have been quoted, with the average trainee requiring 275 procedures. ${ }^{52-54}$ Although a numbers-based approach is easy to document, a broader evaluation is recommended by most learned societies.

\section{Maintaining competency}

A few studies point to a figure of at least 100 procedures per annum in order to maintain competency (ie, a CIR of $\geq 90 \%) .{ }^{55}{ }^{56}$ Other studies have suggested a higher procedural volume of 200-300 may be necessary to maintain competent 
and safe practice with figures below that being associated with lower $\mathrm{CIR}^{56}$ and higher complication rates. ${ }^{5}$ Other markers of competence such as ADR do not appear to correlate well with procedural numbers. ${ }^{57}$

\section{POLYP RETRIEVAL}

Polyps should be retrieved for histological assessment in 90\% of cases.

Following successful polyp removal it is important to retrieve it for histological assessment. This is important to establish the histological nature of the polyp to determine surveillance intervals and to establish the presence of advanced features such as high-grade dysplasia, villous components or cancer. Polyps whose diameter is $<1 \mathrm{~cm}$ are less likely to contain these features; however, retrieval is still important to determine whether there are adenomatous features that determine the need for surveillance. Polyp retrieval is also considered a reflection of the technical skill of the colonoscopist. No evidence correlating polyp retrieval rates with other markers of quality exists. We recommended polyp retrieval rates should be $\geq 90 \%$ in the UK.

\section{TATTOOING OF SUSPECTED MALIGNANT LESIONS IN THE COLON}

Tattooing of all lesions $\geq 20 \mathrm{~mm}$ and/or suspicious of cancer outside of the rectum and caecum should take place in 100\% of cases following local trust guidance.

Tattooing aids the accurate marking of suspected malignant lesions and resection sites, to guide future surgical resection and/or endoscopic surveillance. This technique ${ }^{58}$ has been shown to guide surgical resections safely and accurately. ${ }^{59}$

As polyps increase in size the risk that they harbour cancer increases. All polyps $>2 \mathrm{~cm}$ in diameter should be marked by tattoo. Lesions $<2 \mathrm{~cm}$ in diameter should be assessed by careful inspection and marked if they have high risk features as described in the guidelines of the BCSP. ${ }^{60}$

There should be a clear local policy agreed by the colorectal multidisciplinary team meeting (MDT) defining the number of tattoos and their site relative to the lesion so that there is no ambiguity at the time of surgery or repeat endoscopy. The report should clearly describe the position of tattoos and highlight any potential for confusion if there is more than one set of tattoos in the colon.

\section{DIAGNOSTIC BIOPSIES FOR UNEXPLAINED DIARRHOEA}

$100 \%$ of patients with unexplained diarrhoea to have rectal biopsies.

As an aspiration 100\% of patients with unexplained diarrhoea undergoing colonoscopy to have right and left sided colonic biopsies.

A macroscopically normal examination does not exclude all causes of unexplained diarrhoea, ${ }^{61}$ with the most common diagnosis being microscopic colitis. Microscopic colitis can be patchy and biopsies from both the right and transverse colon are required for diagnosis, ${ }^{62-65}$ a practice reinforced by the American Society for Gastrointestinal Endoscopy (ASGE) guidelines. ${ }^{66}$ We recommend that, unless there is a contraindication, the minimum standard remains that $100 \%$ of patients with unexplained diarrhoea should have rectal biopsies performed. As an aspiration, $100 \%$ of patients undergoing colonoscopy to investigate unexplained diarrhoea should have right and left sided colonic biopsies.

\section{POST-COLONOSCOPY COLORECTAL CANCER RATE}

All units should develop a system for capturing data on and reviewing each case of post-colonoscopy colorectal cancer (PCCRC) as a clinical incident subject to root cause analysis.

Units should aspire to a target of $<5 \%$ PCCRC at 3 years.

There is wide variation in the PCCRC rate from $0 \%$ at mean of 5 years ${ }^{67}$ to $9 \% .{ }^{68}$ Some of this may derive from study design-especially data origin, exclusion criteria and population studied, and from method of calculation used. A recent study ${ }^{69}$ in England between 2001 and 2008 looking at National Cancer Data Repository information and central procedural data shows an $8.5 \%$ overall PCCRC rate for colonoscopies performed between those dates, although the rate fell over time from $10.6 \%$ to $6.8 \%$.

Colonoscopists with high adenoma detection and polypectomy rates provide increased protection for proximal cancers compared with those with lower polypectomy rates. ${ }^{68}$ Specialty and volume of examinations performed have an influence on interval cancer rates. ${ }^{17} 70$ A landmark paper in the New England Journal of Medicine ${ }^{6}$ demonstrated that mucosal visualisation and adenoma detection influence the rate of future cancers.

Polypectomy technique also influences PCCRC, with incomplete polypectomy ${ }^{71}$ contributing to later interval cancers. Pooled North American post-polypectomy studies ${ }^{72}$ demonstrated missed cancer contributing 52\% to the interval cancer rate, with $19 \%$ possibly due to incomplete polyp resection. A further study ${ }^{73}$ found $27 \%$ of interval cancers developed in the same segment as a previous polypectomy, indicating incomplete treatment may have been a contributory factor. Particular emphasis should be placed upon detection of easily missed lesions such as flat, depressed and serrated lesions, particularly in the proximal colon. ${ }^{74} 75$

\section{COMFORT}

Units should audit comfort and $<10 \%$ of patients should have moderate or severe discomfort.

Patient experience of colonoscopy is important and patients should have as comfortable a procedure as possible. A national audit ${ }^{8}$ demonstrated that $10 \%$ of patients experienced moderate or severe discomfort. Although measuring comfort is difficult, a number of scoring systems exist and all units should consistently record patient comfort. Validated measures of patient comfort should be developed.

\section{ADVERSE EVENTS}

Colonoscopy is an invasive procedure, which carries a risk of bleeding, perforation and even death. Although the risk is small with diagnostic colonoscopy, it increases markedly when therapeutic procedures such as polypectomy are performed. It is important that endoscopy units develop QA approaches to investigate adverse events and consider the frequency with which these events might be expected (tables 13 , box 1).

\section{Perforation}

The overall colonoscopic perforation rate is influenced by the proportion of diagnostic to therapeutic procedures performed. In four recent large series overall perforation rates ranged from $0.03 \%$ to $0.085 \% .^{2-5}$ A recent review of studies calculated an overall perforation rate of $0.07 \% .^{76}$ The BSG audit ${ }^{8}$ demonstrated an overall perforation rate of $0.04 \%$. For diagnostic colonoscopy perforation rates of $0-0.2 \%$ are reported. ${ }^{77-79}$ The two main risk factors for 
Table 1 Stratification of bleeding severity

\begin{tabular}{lc}
\hline Criteria & Severity \\
\hline Rectal bleeding within 30 days of procedure resulting in any of the following \\
Procedure aborted & Minor \\
Unplanned post-procedure medical consultation & \\
Unplanned hospital admission, or prolongation of hospital stay, & \\
for $\leq 3$ nights & Intermediate \\
Haemoglobin drop of $\geq 2 \mathrm{~g}$ & \\
Transfusion & \\
Unplanned admission or prolongation for $4-10$ nights & Major \\
ITU admission for 1 night & \\
Interventional procedure (endoscopic or radiological) & Fatal \\
Surgery & \\
Unplanned admission or prolongation for $>10$ nights & \\
ITU admission $>1$ night & \\
Death &
\end{tabular}

post-polypectomy perforation are the size and proximal (caecal) location of polyps. ${ }^{79}$ Two small series reported polypectomy perforation rates of $0.65 \%$ and $0.27 \%$, whereas two slightly larger retrospective series reported rates of $0.11 \%$ and $0.06 \% .{ }^{80-83}$ The recent review of studies calculated the perforation rate in therapeutic colonoscopy to be $0.1 \%,{ }^{76}$ in keeping with the BCSP perforation rate in polypectomy procedures of $0.09 \% .^{79}$

\section{Bleeding}

The risk of post-procedure bleeding is very small with diagnostic colonoscopy, but increases markedly when polypectomy is performed. The two main risk factors are the size and proximal (caecal) location of polyps. ${ }^{79} 81$ Other reported risk factors include co-morbid cardiovascular or chronic renal disease, ${ }^{84}$ age, ${ }^{84-86}$ anticoagulant use ${ }^{84} 85$ and endoscopist experience. ${ }^{85}$ Studies assessing the effect of polyp morphology are inconclusive. ${ }^{79} 8687$ Bleeding rates of $0.3-6.1 \%$ for polypectomies are reported. ${ }^{77} 85$ The recent UK audit reported a bleeding rate of $0.26 \%{ }^{8}$ A recent large series reported a colonoscopy bleeding rate of $0.164 \% .^{5}$ BCSP data illustrate the importance of stratifying bleeding severity: in one study the overall bleeding rate (including many clinically insignificant bleeds) was calculated as $0.59 \%$; limiting the analysis to intermediate or major severity bleeds (haemoglobin drop of $2 \mathrm{~g}$, transfusion, ITU admission, unplanned hospital admission for four or more nights, interventional radiology or endoscopy, or surgery), the rate was $0.13 \% ;^{18}$ and limiting only to bleeding requiring transfusion, the rate was $0.04 \% .^{79}$ We recommend that standardised severity stratification systems are used. ${ }^{88}$

Table 2 Stratification of perforation severity

\begin{tabular}{lc}
\hline Criteria & Severity \\
\hline $\begin{array}{l}\text { Any perforation within } 30 \text { days of procedure should be recorded. } \\
\text { Perforation is defined as evidence of air, luminal contents } \\
\text { or instrumentation outside the gastrointestinal tract }\end{array}$ \\
$\begin{array}{l}\text { Managed conservatively (no endoscopy/surgery) } \\
\text { Endoscopic management }\end{array}$ \\
$\begin{array}{l}\text { Surgery } \\
\text { Death }\end{array}$ \\
\hline Taken from Rutter+Chilton ${ }^{88}$ in turn adapted from Cotton et al. ${ }^{89}$ & \\
\end{tabular}

Table 3 Stratification of other adverse event severity

Criteria Severity

Various other unplanned events may occur as a result of a colonoscopy. These should be recorded, with appropriate details provided

Categorisation of severity of adverse event (AE) is given below.

Note that bleeding and perforation have their own categorisation

(see separate tables) Every event should be recorded, even if it is

deemed unlikely to have been caused by the procedure (see

'Attribution of event')

Excludes admissions for social reasons

Procedure aborted (or not started) due to $\mathrm{AE}$

Unplanned post-procedure medical consultation

Minor

Unplanned hospital admission, or prolonged hospital stay, for $\leq 3$

nights

Use of reversal agent

Hypoxia $\left(\mathrm{O}_{2}\right.$ saturations $\left.<85 \%\right)$

Hypotension $(<90 / 50 \mathrm{~mm} \mathrm{Hg})$

Unplanned admission or prolongation for 4-10 nights

ITU admission for 1 night

Interventional procedure (endoscopic or radiological)

Interventional treatment for skin or other tissue injuries

Unplanned ventilatory support during conscious sedation

Surgery for adverse event/sequelae

Permanent disability

Unplanned admission or prolongation for $>10$ nights

ITU admission $>1$ night

Death

Fatal

Taken from Rutter+Chilton, ${ }^{88}$ in turn adapted from Cotton et al..$^{89}$

ITU, intensive therapy unit.

\section{Box 1 Attribution of event}

It is not always clear whether an adverse event relates to the procedure. After root cause analysis, attribution of adverse events should be recorded as follows

- Definite

- Probable

- Possible

- Unlikely

\section{CONCLUSION}

The agreed QA measures and KPI should be implemented across the UK. Individual endoscopy units are responsible for measuring and acting upon the standards. The JAG will monitor adherence to these standards. Where performance falls below the standards then units should explore and understand underperformance and measures to improve performance should be instituted.

Contributors All authors contributed equally to the development of the manuscript, by authoring a section each, and reviewing and contributing to the other sections.

Competing interests None declared.

Provenance and peer review Not commissioned; externally peer reviewed.

Open Access This is an Open Access article distributed in accordance with the Creative Commons Attribution Non Commercial (CC BY-NC 4.0) license, which permits others to distribute, remix, adapt, build upon this work non-commercially, and license their derivative works on different terms, provided the original work is properly cited and the use is non-commercial. See: http://creativecommons.org/ licenses/by-nc/4.0/

\section{REFERENCES}

1 Rex DK, Cutler C, Lemmel GT, et al. Colonoscopic miss rates of adenomas determined by back-to-back colonoscopies. Gastroenterol 1997;112:24-8. 
2 Arora G, Mannalithara A, Singh G, et al. Risk of perforation from a colonoscopy in adults: a large population-based study. Gastrointest Endosc 2009;69: 654-64.

3 Iqbal CW. Surgical management and outcomes of 165 colonoscopic perforations from a single institution. Arch Surg 2008;143:701-6.

4 Korman LY, Overholt B, Box T, et al. Perforation during colonoscopy in endoscopic ambulatory surgical centers. Gastrointest Endosc 2003;58:554-7.

5 Rabeneck L, Paszat LF, Hilsden RJ, et al. Bleeding and perforation after outpatient colonoscopy and their risk factors in usual clinical practice. Gastroenterol 2008;135:1899-1906.e1.

6 Kaminski MF, Regula J, Kraszewska E, et al. Quality indicators for colonoscopy and the risk of interval cancer. N Eng J Med 2010;362:1795-803.

7 Bowles CJA, Leicester R, Romaya C, et al. A prospective study of colonoscopy practice in the UK today: are we adequately prepared for national colorectal cancer screening tomorrow? Gut 2004;53:277-83.

8 Gavin D, Valori R, Anderson JT, et al. The National Colonoscopy Audit: a nationwide assessment of the quality and safety of colonoscopy in the UK Gut 2013;62:242-9.

9 Rajasekhar PT, Rutter MD, Bramble MG, et al. Achieving high quality colonoscopy: using graphical representation to measure performance and reset standards. Colorectal Dis 2012;14:1538-45.

10 HES data, 2011.

11 Atkin WS, Cook CF, Cuzick J, et al. Single flexible sigmoidoscopy screening to prevent colorectal cancer: baseline findings of a UK multicentre randomised trial. Lancet 2002;359:1291-300.

12 Atkin WS, Edwards R, Kralj-Hans I, et al. Once-only flexible sigmoidoscopy screening in prevention of colorectal cancer: a multicentre randomised controlled trial. Lancet 2010;375:1624-33.

13 Logan RFA, Patnick J, Nickerson C, et al. Outcomes of the Bowel Cancer Screening Programme (BCSP) in England after the first 1 million tests. Gut 2012;61: 1439-46.

14 Aslinia F, Uradomo L, Steele A, et al. Quality assessment of colonoscopic cecal intubation: an analysis of 6 years of continuous practice at a university hospital. Am J Gastroentero/ 2006;101:721-31.

15 Shah HA, Paszat LF, Saskin R, et al. Factors associated with incomplete colonoscopy: a population-based study. Gastroenterol 2007;132:2297-303.

16 Brenner $\mathrm{H}$, Chang-Claude J, Seiler CM, et al. Interval cancers after negative colonoscopy: population-based case-control study. Gut 2012;61:1576-82.

17 Bressler B, Paszat LF, Chen Z, et al. Rates of new or missed colorectal cancers after colonoscopy and their risk factors: a population-based analysis. Gastroenterol 2007;132:96-102.

18 Lee TWJ, Rutter MD, Blanks RG, et al. Colonoscopy quality measures: experience from the NHS Bowel Cancer Screening Programme. Gut 2012;61:1050-7.

19 Corley DA, Jensen CD, Marks AR, et al. Adenoma detection rate and risk of colorectal cancer and death. N Eng J Med 2014;370:1298-306.

20 Francis DL, Rodriguez-Correa DT, Buchner A, et al. Application of a conversion factor to estimate the adenoma detection rate from the polyp detection rate. Gastrointest Endosc 2011;73:493-7.

21 Patel NC, Islam RS, Wu Q, et al. Measurement of polypectomy rate by using administrative claims data with validation against the adenoma detection rate. Gastrointest Endosc 2013;77:390-4.

22 Rajasekhar PT, Lee TJ, Rutter MD, et al. Using a 'conversion factor' to estimate adenoma detection rate. Endoscopy 2012;61(Suppl 3):A371.

23 Rembacken B, Hassan C, Riemann J, et al. Quality in screening colonoscopy: position statement of the European Society of Gastrointestinal Endoscopy (ESGE). Endoscopy 2012:44:957-68.

24 Connor A, Tolan D, Hughes $S$, et al. Consensus guidelines for the safe prescription and administration of oral bowel-cleansing agents. Gut 2012;61:1525-32.

25 Gerard DP, Foster DB, Raiser MW, et al. Validation of a new bowel preparation scale for measuring colon cleansing for colonoscopy: the Chicago bowel preparation scale. Clin Trans/ Gastroenterol 2013;4:e43.

26 Aronchick CA, Lipshutz WH, Wright SH, et al. Validation of an instrument to assess colon cleansing. Am J Gastroenterol 1999;94:2667.

27 Rostom A, Jolicoeur E. Validation of a new scale for the assessment of bowel preparation quality. Gastrointest Endosc 2004;59:482-6.

28 Halphen M, Heresbach D, Gruss H-J, et al. Validation of the Harefield Cleansing Scale: a tool for the evaluation of bowel cleansing quality in both research and clinical practice. Gastrointest Endosc 2013;78:121-31.

29 Lai EJ, Calderwood AH, Doros G, et al. The Boston bowel preparation scale: a valid and reliable instrument for colonoscopy-oriented research. Gastrointest Endosc 2009;69:620-5.

30 Chilton A, Rutter MD. Quality assurance guidelines for colonoscopy. NHS Cancer Screening Programmes, 2011.

31 Cotton PB, Williams CB. Chapter 9. In: Cotton PB, Williams CB, Haycock A, et al. eds. Practical gastrointestinal endoscopy. Wiley-Blackwell, 1996:218-20.

32 El Younis CM. Correlation of preprocedure digital rectal examination and rectal retroflexion during colonoscopy of asymptomatic patients. Gastroenterol Hepatol 2009;5:201-4.
33 Grobe JL, Kozarek RA, Sanowski RA. Colonoscopic retroflexion in the evaluation of rectal disease. Am J Gastroenterol 1982;77:856-8.

34 Cutler AF, Pop A. Fifteen years later: colonoscopic retroflexion revisited. Am J Gastroenterol 1999:94:1537-8.

35 Hanson JM, Atkin WS, Cunliffe WJ, et al. Rectal retroflexion: an essential part of lower gastrointestinal endoscopic examination. Dis Colon Rectum 2001;44:1706-8.

36 Saad A, Rex DK. Routine rectal retroflexion during colonoscopy has a low yield for neoplasia. World J Gastroenterol 2008;14:6503-5.

37 Varadarajulu S, Ramsey WH. Utility of retroflexion in lower gastrointestinal endoscopy. J Clin Gastroenterol 2001;32:235-7.

38 Reddy $A B$, Palardy $L G$, Reddy KB. The utility of rectal retroflexion. Am J Gastroenterol 2011;106:1008-11.

39 Katsinelos P, Kountouras J, Chatzimavroudis G, et al. Endoscopic closure of a large iatrogenic rectal perforation using endoloop/clips technique. Acta Gastroenterol Belg 2009;72:357-9.

40 Sullivan JL, Maxwell PJ IV, Kastenberg DM, et al. Rectal perforation by retroflexion of the colonoscope managed by endoclip closure. Am Surg 2010;76:108-10.

41 Quallick MR, Brown WR. Rectal perforation during colonoscopic retroflexion: a large, prospective experience in an academic center. Gastrointest Endosc 2009;69:960-3.

42 Overholt BF, Brooks-Belli L, Grace $M$, et al. Withdrawal times and associated factors in colonoscopy: a quality assurance multicenter assessment. J Clin Gastroenterol 2010:44:e80-6.

43 Simmons DT, Harewood GC, Baron TH, et al. Impact of endoscopist withdrawal speed on polyp yield: implications for optimal colonoscopy withdrawal time. Aliment Pharmacol Ther 2006;24:965-71.

44 Barclay RL, Vicari JJ, Greenlaw RL. Effect of a time-dependent colonoscopic withdrawal protocol on adenoma detection during screening colonoscopy. Clin Gastroenterol Hepatol 2008;6:1091-8.

45 Gromski MA, Miller CA, Lee $\mathrm{S}-\mathrm{H}$, et al. Trainees' adenoma detection rate is higher if $\geq 10$ minutes is spent on withdrawal during colonoscopy. Surg Endosc 2012;26:1337-42.

46 Lee RH, Tang RS, Muthusamy VR, et al. Quality of colonoscopy withdrawal technique and variability in adenoma detection rates (with videos). Gastrointest Endosc 2011;74:128-34.

47 Moritz $\mathrm{V}$, Bretthauer $\mathrm{M}$, Ruud $\mathrm{H}$, et al. Withdrawal time as a quality indicator for colonoscopy - a nationwide analysis. Surg Endosc 2012;44:476-81.

48 Sawhney MS, Cury MS, Neeman N, et al. Effect of institution-wide policy of colonoscopy withdrawal time $\geq 7$ minutes on polyp detection. Gastroenterol 2008;135:1892-8.

49 British Society of Gastroenterology Safety and sedation during endoscopic procedures, 2003.

50 Rajasekhar PT, Clifford GM, Lee TJW, et al. Bowel cancer screening is safe, detects earlier stage cancer and adenomas in $50 \%$ of cases: experience of the prevalent round of screening from two first wave centres in the North East of England. Frontline Gastroenterol 2012;3:10-15.

51 Ward ST, Mohammed MA, Walt R, et al. An analysis of the learning curve to achieve competency at colonoscopy using the JETS database. Gut 2014;63:1746-54.

52 Spier BJ, Benson M, Pfau PR, et al. Colonoscopy training in gastroenterology fellowships: determining competence. Gastrointest Endosc 2010;71:319-24.

53 Sedlack RE. Training to competency in colonoscopy: assessing and defining competency standards. Gastrointest Endosc 2011;74:355-366.e1-2.

54 Park HJ, Hong JH, Kim HS, et al. Predictive factors affecting cecal intubation failure in colonoscopy trainees. BMC Med Educ 2013;13:5.

55 Wexner SD, Garbus JE, Singh JJ. A prospective analysis of 13,580 colonoscopies. Reevaluation of credentialing guidelines. Surg Endosc 2001;15:251-61.

56 Harewood GC. Relationship of colonoscopy completion rates and endoscopist features. Dig Dis Sci 2005;50:47-51.

57 Adler A, Wegscheider K, Lieberman D, et al. Factors determining the quality of screening colonoscopy: a prospective study on adenoma detection rates, from 12 134 examinations (Berlin colonoscopy project 3, BECOP-3). Gut 2013;62:236-41.

58 Ponsky JL, King JF. Endoscopic marking of colonic lesions. Gastrointest Endosc 1975;22:42-3.

59 Mcarthur CS, Roayaie S, Waye JD Safety of preoperation endoscopic tattoo with India ink for identification of colonic lesions. Surg Endosc 1999;13:543-6.

60 Bowel Cancer Screening Programme. BCSP Tattooing Policy, 2012.

61 Fine KD, Seidel RH, Do K. The prevalence, anatomic distribution, and diagnosis of colonic causes of chronic diarrhoea. Gastrointest Endosc 2000;51:318.

62 Williams JJ, Beck PL, Andrews CN, et al. Microscopic colitis-a common cause of diarrhoea in older adults. Age Ageing 2010;39:162-8.

63 Pardi DS, Loftus EV, Smyrk TC, et al. The epidemiology of microscopic colitis: a population based study in Olmsted County, Minnesota. Gut 2007;56:504-8

64 Carpenter HA, Tremaine WJ, Batts KP, et al. Sequential histologic evaluations in collagenous colitis. Correlations with disease behavior and sampling strategy. Dig Dis Sci 1992;37:1903-9.

65 Tanaka M, Mazzoleni G, Riddell RH. Distribution of collagenous colitis: utility of flexible sigmoidoscopy. Gut 1992;33:65-70. 
66 Shen B, Khan K, Ikenberry SO, et al. The role of endoscopy in the management of patients with diarrhea. Gastrointest Endosc 2010;71:887-92.

67 Imperiale TF, Glowinski EA, Lin-Cooper C, et al. Five-year risk of colorectal neoplasia after negative screening colonoscopy. N Eng J Med 2008;359:1218-24.

68 Baxter NN, Sutradhar R, Forbes SS, et al. Analysis of administrative data finds endoscopist quality measures associated with postcolonoscopy colorectal cancer. Gastroenterol 2011;140:65-72.

69 Morris EJ, Rutter MD, Finan PJ, et al. Post-colonoscopy colorectal cancer (PCCRC) rates vary considerably depending on the method used to calculate them: a retrospective observational population-based study of PCCRC in the English National Health Service. Gut 2015;64:1248-56.

70 Singh $H$, Nugent $Z$, Demers AA, et al. Rates and predictors of early/missed colorectal cancers after colonoscopy in Manitoba: a population-based study. Am J Gastroenterol 2010;105:2588-96.

71 Pabby A, Schoen RE, Weissfeld JL, et al. Analysis of colorectal cancer occurrence during surveillance colonoscopy in the dietary polyp prevention trial. Gastrointest Endosc 2005;61:385-91.

72 Robertson DJ, Lieberman D, Winawer SJ, et al. Colorectal cancers soon after colonoscopy: a pooled multicohort analysis. Gut 2014;63:949-56.

73 Farrar WD, Sawhney MS, Nelson DB, et al. Colorectal cancers found after a complete colonoscopy. Clin Gastroenterol Hepatol 2006;4:1259-64.

74 Rondagh EJA, Bouwens MWE, Riedl RG, et al. Endoscopic appearance of proximal colorectal neoplasms and potential implications for colonoscopy in cancer prevention. Gastrointest Endosc 2012;75:1218-25.

75 Kahi CJ, Imperiale TF, Juliar BE, et al. Effect of screening colonoscopy on colorectal cancer incidence and mortality. Clin Gastroenterol Hepatol 2009:7:770-5.

76 Panteris V, Haringsma J, Kuipers EJ. Colonoscopy perforation rate, mechanisms and outcome: from diagnostic to therapeutic colonoscopy. Endoscopy 2009:41:941-51.

77 Nelson DB, Mcquaid KR, Bond JH, et al. Procedural success and complications of large-scale screening colonoscopy. Gastrointest Endosc 2002;55:307-14.
78 Silvis SE, Nebel O, Rogers G, et al. Endoscopic complications. Results of the 1974 American Society for Gastrointestinal Endoscopy Survey. JAMA 1976;235:928-30.

79 Rutter MD, Nickerson C, Rees C, et al. Risk factors for adverse events related to polypectomy in the English Bowel Cancer Screening Programme. Endoscopy 2014;46:90-7.

80 Gondal G, Grotmol T, Hofstad B, et al. The Norwegian Colorectal Cancer Prevention (NORCCAP) Screening Study: baseline findings and implementations for clinical work-up in age groups 50-64 years. Scand J Gastroenterol 2003;38:635-42

81 Heldwein W, Dollhopf M, Rösch T, et al. The Munich Polypectomy Study (MUPS): prospective analysis of complications and risk factors in 4000 colonic snare polypectomies. Endoscopy 2005;37:1116-22.

82 Levin TR. Complications of colonoscopy in an integrated health care delivery system. Ann Intern Med 2006;145:880-6.

83 Sieg A, Hachmoeller-Eisenbach U, Eisenbach T. Prospective evaluation of complications in outpatient $\mathrm{Gl}$ endoscopy: a survey among German gastroenterologists. Gastrointest Endosc 2001;53:620-7.

$84 \mathrm{Kim} \mathrm{HS}$, Kim TI, Kim WH, et al. Risk factors for immediate postpolypectomy bleeding of the colon: a multicenter study. Am J Gastroenterol 2006;101:1333-41.

85 Rosen L, Bub DS, Reed JF, et al. Hemorrhage following colonoscopic polypectomy. Dis Colon Rectum 1993;36:1126-31.

86 Saraya T, Ikematsu $\mathrm{H}$, Fu Kl, et al. Evaluation of complications related to therapeutic colonoscopy using the bipolar snare. Surg Endosc 2012;26:533-40.

87 Buddingh KT, Herngreen T, Haringsma J, et al. Location in the right hemi-colon is an independent risk factor for delayed post-polypectomy hemorrhage: a multi-center case-control study. Am J Gastroenterol 2011;106:1119-24.

88 Rutter MD, Chilton A. Quality Assurance Guidelines for Colonoscopy. NHS BCSP Publication, 2011:6:24.

89 Cotton PB, Eisen GM, Aabakken L, et al. A lexicon for endoscopic adverse events: report of an ASGE workshop. Gastrointest Endosc 2010;71:446-54. 